\title{
Exploration of Physico-Chemical Parameters in Environmental Matrices of the River Cerica and a Segment of the River Drini I Bardhë
}

\author{
Naser Bajraktari', Granit Kastrati ${ }^{*}$, llir Morina', Ylber Bajraktari² \\ 1 Faculty of Agroecology and Agroenvironment, University of Peja 'Haxhi Zeka', St. UÇK 30000, Pejë, Kosovo \\ 2 AAB College, Industrial zone, Pristina, Kosovo \\ * Corresponding author's e-mail: granit.kastrati@unhz.eu
}

\begin{abstract}
A study investigated physicochemical parameters in environmental matrices along the river Cerica waters. A correlation between the actual level of pollution of this river and its impact on the Drini i Bardhë River was determined. The extent of its pollution, was conducted following the identification of pollution sources, which consequently allowing to determine the necessary steps for their isolation. The monitoring of heavy metals, physicochemical parameters, nutrients was carried out in all country-sample (locations). In particular, there where are significant sources of pollution of surface waters, as a result of industrial activities and wastewater discharge. Determining of the locations and heavy metals concentrations was carried out in sediments and agricultural lands in this region, with the purpose to reflect the actual stat.
\end{abstract}

Keywords: Drini i Bardhë, Cerica, water quality, sediment, soil, pollution, monitoring.

\section{INTRODUCTION}

Water resources are of great importance to human life and economy as well as constitute the main source of drinking water needs, irrigation of agricultural land and industry. Therefore, water shortage is considered as a limiting factor of socio-economic development of a country. Additionally, population growth, environmental pollution, and climate change are the three major factors that lead to the continual reduction of water in the world. The available freshwater quantity is constant, it cannot be added. This means that we must rationally use the existing amount of drinking water. Worldwide, around $70 \%$ of drinking water is used for irrigation, $20 \%$ for industry and less than $10 \%$ for household needs, as potable water [Report, UN, Bon, 2003].

In post-war Kosovo, there is a clear lack of water protection. While there is a tendency to revive the economy, relying on the activation of the old inherited technologies, the financial inability to introduce contemporary technologies, obsolete water infrastructure in urban areas, the lack of wastewater treatment, the dumping of industrial and urban waste in inadequate places, constitute a source of water pollution [Bajraktari, et all, 2004].

Cerica River, in most cases, serves as a main supplier during the summer season with irrigation water for fields and agricultural land for Rahovec locality. The river flows into the Zatriqi Mountains, passes near the city of Rahovec, the Wine Factory and some villages affected by some other streams as well as the drainage of agricultural lands planted with different cultures. Recently, the river has become a collector of urban and industrial wastewater in this area. The last stream of this river ends in the Drini i Bardhë river basin. Some of the heavy metals: $\mathrm{Pb}, \mathrm{Cu}, \mathrm{Ni}, \mathrm{Cd}, \mathrm{Fe}, \mathrm{Zn}$, $\mathrm{Mn}, \mathrm{Cr}$ and $\mathrm{Li}$, were analyzed from the samples collected at certain locations along the course of the Cerica River (water, sediment and agricultural land samples). Certain physicochemical and macro-pollutant parameters such as: biochemical oxygen demand $-\mathrm{BOD}_{5}$, dissolved oxygen and other chemical indicators (ammonia, nitrites, nitrates, etc.) were analyzed as well. 


\section{MATERIAL AND METHOD}

\section{Apparatus and Reagents}

All the chemicals needed for the determination of physicochemical parameters, micro-pollutants and macro-pollutants during the analysis of surface water samples and agricultural lands were of chemical purity "pro analysis" (p.a.). AAS Pekin-Elmer analyzer 400, Spectrophotometer UV \& VIS secomam, Photometer PF-11 nanocolor-viscocolor, conductivity / TDS Meter Toledo NC126, pH meter consort C830, turbidimeter Aquatic NTU/FNU, mineralizing (microwawe) Ethos D Milestone were used for measuring heavy metals. Additionally, filtering of samples was done with (Millipore Millex-FH) Hydrophobic PTFE $0.45 \mu \mathrm{m}$ filters.

\section{Working methods}

The techniques used to define the parameters were the standard methods of analysis and instrumental methods of analysis. The appliances used were those with the purpose of determining the specified parameter according to the methods given. [Standard Methods, 18th Edition, 1992].

\section{Samples}

Sampling was done on the basis of a preliminary study in such a way that the sampling sites of water and soil have a certain and appropriate distance to see their influence among themselves.
Sampling was performed using standard equipment. [Standard Methods, 18th Edition, 1992].

The accuracy of the analytical results of the laboratory was verified by the General Association of Environmental Analysis Laboratories AGLAE. Test code: 08M1A3, date: 4/11/2008, which was attended by 136 labs, made in the same sampling period with our research on Cerica River. According to this association, the results of the reference samples were acceptable.

\section{Scope of study}

Rivers are perhaps the most harmonized aquatic systems, when it comes to the transport and interaction of microelements, especially heavy metals. Because of the rapid flow of river water, rocks interactions of the sedimentation surface of the riverbed, are very intense, for each part of the river flow brings little or much change to the river's content [Polic, et al., 1999]. The sub-basin selected for the study explores different types of land, rocks and human activities. These rocks occupy most of the Rahovec massif. They represent together with the basic measure in which all other varieties of ultramafic complex are introduced. Their main components are: olivine, enstatite, monoclinal pyroxene. The secondary minerals are: terpentine, talc, chromite, etc. The modal composition of the serpentinized fighters is: oligonas $60-0 \%$, serpentine $30-90 \%$, enacted $15-0 \%$, monoclinal pyroxene or secondary amphibole derived from it up to $2 \%$, talc to $5 \%$, chromium up to $2,5 \%$, iron oxides up to $4 \%$. [Fejza, 2004]

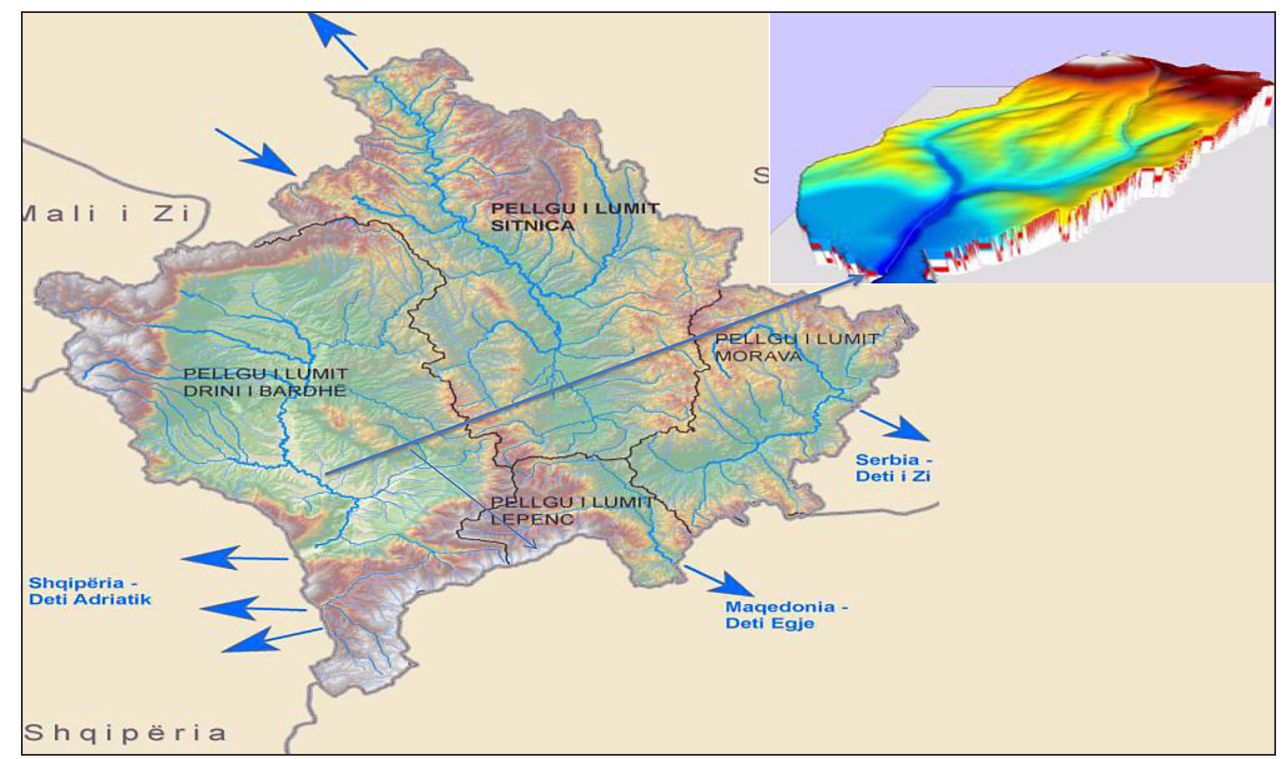

Fig. 1. Presentation of site-sampling along the River Cerica and the Drini i Bardhe River. 
While these heavy metal waters are used for irrigation in agriculture, it is acceptable that the collection of these metals in the soils where these plants grow and their use by humans and animals will be adversely affected. During this three year research period (2006-2008), the waters of the Rahovec region and a part of the Drini i Bardhë basin were investigated.

\section{RESULTS AND DISCUSSION}

The monitoring of elements and substances classified as micro-pollutants (heavy metals) was studied and monitored at all site sampling sites, where other parameters were researched, and in particular where there are strong sources of water pollution, especially by industry and polluted waters. Pollution has damaged enough flora and fauna, especially those that grow and live on the banks of river and water canals. The water classification of this sub-basin (river) and basin was made based on several water quality indicators at different sampling periods, compared to the parameters given in Table 1, according to UNECE.

Investigation on the results change on analysed parameters at the sampling points was carried out with the ANOVA and T test. The obtained values are expressed in medium value \pm SDev. For this purpose, an incomplete factorial design was optimized: firstly, for applying statistical tests, it was assumed that the three values for each parameter are different. In this way, the $T$ values for each parameter between the sampling points are calculated.

The research results along the course of the Cerica River and Drini i Bardhë are presented in a form of table (2-4), as well as in graphical form for some parameters.

\section{Water Temperature}

On the basis of the results obtained from six measuring stations in the Cerica River and Drini i Bardhë, the water temperature values varied from $17.73^{\circ} \mathrm{C}$ to $19.14^{\circ} \mathrm{C}$, at I-Urae Drenocitstationand VI - Krajk station, respectively, the average value was $10.4^{\circ} \mathrm{C}$. The water temperature in this river indicates a downward trend at the stream bottom.

\section{The Concentration of Hydrogen lons $(\mathrm{pH})$}

The average value measured at six stations in Cerica River and Drini i Bardhë indicates that the water is alkaline. The $\mathrm{pH}$ values exhibited small variations (a minimum value of 7.71 and a maximum value of 8.39 , the average value being 8.04, as seen from the respective values of DS and Cv. This narrow variation of $\mathrm{pH}$ values indicates that there is no significant impact of civil and industrial discharges in the monitored surface water flow. The $\mathrm{pH}$ values monitored in the water of Cerica River and Drini i Bardhë were compared with the respective values of the UNECE standard. The measured $\mathrm{pH}$ values in the water of Cerica River and Drini i Bardhë lie in the normal range at all six measuring stations, based on this comparison.

\section{The Electrical Conductivity $x[\mu \mathrm{S} / \mathrm{cm}-1]$}

In principle, water conductivity shows an upward trend in dry seasons with low rainfall. The change in electrical conductivity of the water at a constant temperature is closely related to the change of water mineralization. It is an important indicator to hydrogeological research. The lowest (minimum) value was obtained at the measuring station V- Xerxe $\left(412.2 \mu \mathrm{S} / \mathrm{cm}^{-1}\right)$, whereas the maximum value was obtained at the measuring station III - Fortesë $\left(805.8 \mu \mathrm{S} / \mathrm{cm}^{-1}\right)$, the average value being $626.2\left(\mu \mathrm{S} / \mathrm{cm}^{-1}\right)$.

\section{Total Dissolved salts TDS [mg/l]}

The TDS parameter values varied from $181 \mathrm{mg} / \mathrm{l}$ to $388 \mathrm{mg} / \mathrm{l}$. The minimum value of $181 \mathrm{mg} / \mathrm{l}$ was obtained at $\mathrm{V}-$ Xerxe station, the maximum value of $388 \mathrm{mg} / \mathrm{l}$ was obtained at the measuring station III - Fortesë, the average TDS value being $303.1 \mathrm{mg} / \mathrm{l}$.

Table 1. Classification of river quality by UNECE (content, mg/l)

\begin{tabular}{|c|c|c|c|c|c|c|}
\hline Category & $\mathrm{P}_{\text {total }}$ & $\mathrm{NO}_{3}^{-}$ & $\mathrm{OT}$ & $\mathrm{BOD}_{5}$ & $\mathrm{COD}$ & $\mathrm{NH}_{4}{ }^{+}$ \\
\hline $\mathrm{I}$ & $<10$ & $<5$ & $>7$ & $<3$ & $<3$ & $<0.1$ \\
\hline $\mathrm{II}$ & $10-25$ & $5-25$ & $7-6$ & $3-5$ & $3-10$ & $0.1-0.5$ \\
\hline $\mathrm{III}$ & $25-50$ & $25-50$ & $6-4$ & $5-9$ & $10-20$ & $0.5-2$ \\
\hline $\mathrm{IV}$ & $50-125$ & $50-80$ & $4-3$ & $9-15$ & $20-30$ & $2-8$ \\
\hline $\mathrm{V}$ & $>125$ & $>80$ & $<3$ & $>15$ & $>30$ & $>8$ \\
\hline
\end{tabular}


Table 2. The results of the analysis in the water samples (the average of the five sampling periods)

\begin{tabular}{|c|c|c|c|c|c|c|c|}
\hline \multirow{2}{*}{ Parameters } & \multirow{2}{*}{ Units } & \multicolumn{3}{|c|}{ Cerica } & \multicolumn{3}{|c|}{ Drini i Bardhë } \\
\hline & & I- Ura Drenocit & II- M. Aliagës & III- Fortesë & IV- Rugovë & V-Xerxe & VI- Krajk \\
\hline T. ${ }_{\mathrm{H} 2 \mathrm{O}}$ & $\mathrm{C}$ & 17.78 & 18.82 & 18.84 & 18.42 & 19.18 & 19.14 \\
\hline T. Air $_{\text {n }}$ & $\mathrm{C}$ & 22.36 & 22.84 & 23.2 & 22.92 & 23.28 & 22.68 \\
\hline $\mathrm{pH}$ & - & 8.39 & 7.73 & 7.71 & 8 & 8.21 & 8.21 \\
\hline Turbidity & NTU & 0.6 & 95.1 & 86 & 79.9 & 23 & 24.7 \\
\hline TDS & $\mathrm{mg} / \mathrm{l}$ & 359 & 381 & 388 & 302 & 181 & 208 \\
\hline Conductivity & $\mu S / c m$ & 727.4 & 769 & 805.8 & 606.4 & 412.2 & 436.4 \\
\hline $\mathrm{NH}_{4}$ & $\mathrm{mg} / \mathrm{l}$ & 0.37 & 14.97 & 12.32 & 6.9 & 0.37 & 0.36 \\
\hline $\mathrm{NO}_{3}$ & $\mathrm{mg} / \mathrm{l}$ & 0.86 & 3.9 & 4.46 & 2.6 & 2.66 & 2.54 \\
\hline $\mathrm{NO}_{2}$ & $\mathrm{mg} / \mathrm{l}$ & 0.007 & 0.105 & 0.102 & 0.083 & 0.023 & 0.026 \\
\hline $\mathrm{PO}_{4}$ & $\mathrm{mg} / \mathrm{l}$ & 0.06 & 4.07 & 3.22 & 2.31 & 0.2 & 0.2 \\
\hline $\mathrm{BOD}_{5}$ & $\mathrm{mg} / \mathrm{l}$ & 5.8 & 12.73 & 12.67 & 10.25 & 5.95 & 4.46 \\
\hline $\mathrm{O}_{2} \%$ & $\mathrm{mg} / \mathrm{l}$ & 55.3 & 11.46 & 33.35 & 49.77 & 99.29 & 91.99 \\
\hline OD & $\mathrm{mg} / \mathrm{l}$ & 5.01 & 1.08 & 3.21 & 4.53 & 8.66 & 8.93 \\
\hline $\mathrm{SO}_{4}$ & $\mathrm{mg} / \mathrm{l}$ & 5.92 & 60.99 & 60.77 & 54.54 & 12.08 & 12.27 \\
\hline $\mathrm{Cu}$ & $\mathrm{mg} / \mathrm{l}$ & 0.075 & 0.043 & 0.039 & 0.036 & 0.004 & 0.002 \\
\hline $\mathrm{Cd}$ & $\mathrm{mg} / \mathrm{l}$ & 0.005 & 0.003 & 0.003 & 0.004 & 0.002 & 0.002 \\
\hline $\mathrm{Ni}$ & $\mathrm{mg} / \mathrm{l}$ & 0.23 & 0.07 & 0.07 & 0.07 & 0.05 & 0.05 \\
\hline $\mathrm{Pb}$ & $\mathrm{mg} / \mathrm{l}$ & 0.06 & 0.05 & 0.05 & 0.03 & 0.04 & 0.04 \\
\hline $\mathrm{Li}$ & $\mathrm{mg} / \mathrm{l}$ & 0.1 & 0.08 & 0.08 & 0.08 & 0.05 & 0.05 \\
\hline $\mathrm{Fe}$ & $\mathrm{mg} / \mathrm{l}$ & 3.32 & 1.4 & 1.48 & 1.42 & 1.29 & 1.27 \\
\hline $\mathrm{Cr}$ & $\mathrm{mg} / \mathrm{l}$ & 0.09 & 0.052 & 0.05 & 0.058 & 0.009 & 0.018 \\
\hline $\mathrm{Zn}$ & $\mathrm{mg} / \mathrm{l}$ & 0.062 & 0.043 & 0.039 & 0.036 & 0.009 & 0.009 \\
\hline
\end{tabular}

\section{Ammonium $\mathrm{NH}_{4}{ }^{+}[\mathrm{mg} / \mathrm{l}]$}

Ammonium is present in many surface glasses of water and groundwater. As such, it results from the microbiological activity of the dissolution of organic compounds of nitrogen. Its presence in the water is indicative of a new organic pollution. The ammonia risk in water depends on temperature, $\mathrm{pH}$ value, oxygen and dissolved carbon dioxide. The monitoring and analysis of this parameter in the water of Cerica River and Drini i Bardhë showed the value from $12.32 \mathrm{mg} / 1$ (III - Fortesë) to $0.36 \mathrm{mg} / \mathrm{l}$ (VI - Krajk), the average $\mathrm{NH}^{4+}$ value being $5.88 \mathrm{mg} / \mathrm{l}$.

\section{Nitrates $\mathrm{NO}_{3}^{-}[\mathrm{mg} / \mathrm{ll}]$}

Nitrates constitute a higher degree of oxidation of the nitrogen in nature. The drinking water must not contain more than $15 \mathrm{mg} / \mathrm{dm}^{3}$ of nitrate as nitrogen. In surface waters, they are present in small quantities, whereas in groundwater they are found in larger amounts. Nitrates are present the final product of biological oxidation of organic pollution. This indicates that the water was polluted in the past. The minimum value was $0.86 \mathrm{mg} / \mathrm{l}$ (I - Ura e Drenocit), the maximum value was $4.46 \mathrm{mg} / \mathrm{l}$ (III -Fortesë), the average value is $2.4 \mathrm{mg} / \mathrm{l}$.

\section{Nitrites $\mathrm{NO}_{2}{ }^{-}[\mathrm{mg} / \mathrm{l}]$}

Nitrites are toxic and the maximal acceptable amount in drinking water is $0.005 \mathrm{mg} / \mathrm{dm}^{3}$ of nitrite. The obtained results at the sampling stations of Cerica River and Drini i Bardhë showed the following values: at station I-Ura e Drenocit, the minimum value was $0.007 \mathrm{mg} / \mathrm{l}$, while the maximum value was $0.102 \mathrm{mg} / \mathrm{l}$, obtained at II - Mulliri i Aliagës, the average value was $0.057 \mathrm{mg} / 1$.

\section{Phosphate ions $\mathrm{PO}_{4}^{3-}$}

The maximum values were obtained at II Mulliri i Aliagës station $(4.07 \mathrm{mg} / \mathrm{l})$, whereas the lowest values were obtained at Drini i Bardhë river; at V - Xerxe station and at VI - Krajkë station, the values were $0.2 \mathrm{mg} / \mathrm{l}$, thus the average value was $1.67 \mathrm{mg} / 1$.

\section{Sulfates $\mathrm{SO}_{4}{ }^{2-}[\mathrm{mg} / \mathrm{l}]$}

Sulfates pose a threat to water bodies in that they provoke anaerobic phenomena during their 
Table 3. Analysis results in sediment samples (average of five sampling periods)

\begin{tabular}{|c|c|c|c|c|c|c|c|}
\hline \multirow{2}{*}{ Parameters } & \multirow{2}{*}{ Units } & \multicolumn{3}{|c|}{ Cerica } & \multicolumn{3}{c|}{ Drini i Bardhë } \\
\cline { 3 - 8 } & & I- Ura Drenocit & II- M. Aliagës & III- Fortese & IV- Rugove & V-Xerxe & VI- Krajk \\
\hline $\mathrm{T}_{\text {H2O }}$ & ${ }^{\circ} \mathrm{C}$ & 17.78 & 18.82 & 18.84 & 18.42 & 19.18 & 19.14 \\
\hline $\mathrm{T} .{ }_{\text {Air }}$ & ${ }^{\circ} \mathrm{C}$ & 22.36 & 22.84 & 23.2 & 22.92 & 23.28 & 22.68 \\
\hline $\mathrm{pH}$ & & 8.39 & 7.73 & 7.71 & 8 & 8.21 & 8.21 \\
\hline $\mathrm{Cu}$ & $\mathrm{mg} / \mathrm{kg}$ & 83.22 & 79.14 & 75.6 & 72.16 & 61.52 & 66.68 \\
\hline $\mathrm{Cd}$ & $\mathrm{mg} / \mathrm{kg}$ & 0.434 & 0.298 & 0.354 & 0.338 & 0.253 & 0.246 \\
\hline $\mathrm{Ni}$ & $\mathrm{mg} / \mathrm{kg}$ & 166.2 & 51.48 & 61.82 & 64.45 & 7.01 & 8.41 \\
\hline $\mathrm{Pb}$ & $\mathrm{mg} / \mathrm{kg}$ & 28.27 & 23.35 & 24.59 & 22.95 & 14.9 & 14.9 \\
\hline $\mathrm{Li}$ & $\mathrm{mg} / \mathrm{kg}$ & 125.8 & 99.6 & 101 & 100.6 & 34 & 37.2 \\
\hline $\mathrm{Fe}$ & $\mathrm{mg} / \mathrm{kg}$ & 2626.6 & 2684.8 & 2563.8 & 2419.6 & 2340.2 & 2389.8 \\
\hline $\mathrm{Zn}$ & $\mathrm{mg} / \mathrm{kg}$ & 23.6 & 17.6 & 17.7 & 16.5 & 10.2 & 12.8 \\
\hline $\mathrm{Cr}$ & $\mathrm{mg} / \mathrm{kg}$ & 24.3 & 15.9 & 15.2 & 14.9 & 12.5 & 12 \\
\hline
\end{tabular}

Table 4. Analysis results in soil samples (average of three sampling periods)

\begin{tabular}{|c|c|c|c|c|c|c|c|}
\hline \multicolumn{8}{|c|}{ Depth: $5-15 \mathrm{~cm}$ and $55-65 \mathrm{~cm}$} \\
\hline \multirow{2}{*}{ Parameters } & \multirow{2}{*}{ Units } & \multicolumn{2}{|c|}{ Cerica } & \multirow{2}{*}{$\begin{array}{l}\text { D. Bardhë } \\
\text { III } 5-15 \mathrm{~cm}\end{array}$} & \multicolumn{2}{|c|}{ Cerica } & \multirow{2}{*}{$\begin{array}{c}\text { D. Bardhë } \\
\text { II 55-65 cm }\end{array}$} \\
\hline & & I 5-15 cm & II 5-15 cm & & I $55-65 \mathrm{~cm}$ & II $55-65 \mathrm{~cm}$ & \\
\hline Culture & & meadow & field & vegetable & meadow & field & vegetable \\
\hline Soil type & & Smonic & $\begin{array}{c}\text { Aluvio- } \\
\text { deluvional }\end{array}$ & Aluvium & Smonic & $\begin{array}{c}\text { Aluvio- } \\
\text { deluvional }\end{array}$ & Aluvium \\
\hline $\mathrm{T}_{\text {Air }}$ & C & 22.36 & 22.84 & 23.2 & 22.92 & 23.28 & 22.68 \\
\hline $\mathrm{pH}$ & - & 8.39 & 7.73 & 7.71 & 8 & 8.21 & 8.21 \\
\hline $\mathrm{Cu}$ & $\mathrm{mg} / \mathrm{kg}$ & 91.7 & 76.3 & 80.77 & 69.83 & 77.17 & 70 \\
\hline $\mathrm{Cd}$ & $\mathrm{mg} / \mathrm{kg}$ & 0.05 & 0.05 & 0.12 & 0.05 & 0.07 & 0.12 \\
\hline $\mathrm{Ni}$ & $\mathrm{mg} / \mathrm{kg}$ & 273.3 & 78.8 & 72.5 & 379.8 & 85.5 & 96.8 \\
\hline $\mathrm{Pb}$ & $\mathrm{mg} / \mathrm{kg}$ & 12.2 & 17.2 & 24.5 & 12 & 20.9 & 22.6 \\
\hline $\mathrm{Li}$ & $\mathrm{mg} / \mathrm{kg}$ & 39.7 & 119.3 & 101.7 & 45 & 124 & 117 \\
\hline $\mathrm{Fe}$ & $\mathrm{mg} / \mathrm{kg}$ & 22983 & 17973 & 18460 & 35190 & 18923 & 31903 \\
\hline $\mathrm{Zn}$ & $\mathrm{mg} / \mathrm{kg}$ & 148.7 & 75 & 57 & 179.7 & 153.7 & 76 \\
\hline $\mathrm{Cr}$ & $\mathrm{mg} / \mathrm{kg}$ & 22.43 & 18.04 & 15.05 & 22.52 & 17.55 & 15.09 \\
\hline
\end{tabular}

transformation into sulfate by consuming the water oxygen. This indicator in the water of Cerica River at the three stations I - Ura e Drenocit, II Mulliti i Aliagës, III -Fortesë showed the values of $5.92 \mathrm{mg} / 1,60.99 \mathrm{mg} / 1$ and at III - Fortesë station $60.77 \mathrm{mg} / 1$, while for Drini i Bardhë River at the three stations IV - Rugovë, V - Xerxe, VI - Krajk the values of $54.54 \mathrm{mg} / 1,12.08$ and $12.27 \mathrm{mg} / 1$ were found, respectively.

\section{Biological Oxygen Demand $\left(\mathrm{BOD}_{5}\right)$}

Figure 2 presents the results for $\mathrm{BOD}_{5}$ as a chemical parameter in 6 sampling points across Cerica River and Drini i Bardhë in 5 different time periods within a year. At the sampling point I - Ura e Drenocit and V - D.B. Rugovë, the average results were: Xmes $5.80 \mathrm{mg} / \mathrm{l}-$ $5.95 \mathrm{mg} / 1$, whereas $\mathrm{Sdev}-3.90 \mathrm{mg} / 1$ at $3.63 \mathrm{mg} / 1$, which indicates that the waters of this part along the Cerica River are classified as $3^{\text {rd }}$ class waters. As for the sampling points II - Mulliri i Aliagës, III - Fortesë dhe IV - Xerxe the average of the results were Xmes having an average value of $12.73 \mathrm{mg} / 1,12.67 \mathrm{mg} / \mathrm{l}$ and $10.25 \mathrm{mg} / \mathrm{l}$, whereas Sdev $-5.13 \mathrm{mg} / 1,5.69 \mathrm{mg} / 1$ and $4.56 \mathrm{mg} / 1$. The results obtained in these sampling sites show that this water is clasiffied as $4^{\text {th }}$ class. In the sampling point IV - D.B. Krajk, the results for Xmes were $4.46 \mathrm{mg} / 1$ and Sdev - 2.52, which indicates that these waters belong to the waters of second class.

Figure 3 shows the values for the Ni analysis on the samples of river Cerica and Drini $i$ Bardhë for six sampling points and for five different periods of time within the year. A change of values was noticed regarding the quantity of $\mathrm{Ni}$ in these waters on the basis of the results presented in Figure 3.

At the sampling point I - Ura e Drenocit, Xmes and Sdev, the obtained values were: 
$0.21 \mathrm{mg} / 1$ and $0.118 \mathrm{mg} / 1$. In the case of the sampling points II - Mulliri i Aliagës, III - Fortesë and IV - Xerxe the amount of $\mathrm{Ni}$ in these samples shows approximately similar values: $0.07 \mathrm{mg} / \mathrm{l}$, as for the sampling sites V-D.B Rugove and IV - D.B. Krajk, the amount of Nickel is even lower, around $0.05 \mathrm{mg} / \mathrm{l}$.

Figure 4 shows the values of $\mathrm{Ni}$ for the sample of sediments in six different sampling points and in five different time periods within a year; the results for each sampling point were obtained by analysing these samples. In the sampling point I - Ura e Drenocit, the Xmes and Sdev values for $\mathrm{Ni}$ are expressed in $\mathrm{mg} / \mathrm{kg}$ and amount to 166.2 , and $57.52 \mathrm{mg} / \mathrm{kg}$, respectively, whereas for the sampling points II, III and IV the results of the analysis have approximate values, which are $51.48 \mathrm{mg} / \mathrm{kg}, 61.82 \mathrm{mg} \mathrm{kg}$ and $64.45 \mathrm{mg} / \mathrm{kg}$. As far as the last two station points V and VI, the amount of Ni shows lower values compared to the previous sampling sites of the same river. For the sampling point $\mathrm{V}-\mathrm{Xerxe}$, Xmes and Sdev amount to $7.01 \mathrm{mg} \mathrm{kg}$, and $10.64 \mathrm{mg} / \mathrm{kg}$, respectively, whereas for the sampling point VI-Krajkë, the Xmes and Sdev values are $8.41 \mathrm{mg} / \mathrm{kg}$ and $12.95 \mathrm{mg} / \mathrm{kg}$, respectively.

The analysed values for $\mathrm{Ni}$ in soil samples for three different time periods within a year are presented in Fig. 5. The samples were taken in different depths from 5 to $15 \mathrm{~cm}$, and $55-65 \mathrm{~cm}$. For the values of the three sampling points and the periods in depth of 5-15 cm, the obtained results for Xmes and Sdev at the sampling point I were $273.3 \mathrm{mg} / \mathrm{kg}$ and $15.28 \mathrm{mg} \mathrm{kg}$, respectively, while at the sampling points II and III, more approximate values were obtained; therefore, for the sampling point II Xmes the value was $78.8 \mathrm{mg} / \mathrm{kg}$ and for Sdev $-5.58 \mathrm{mg} / \mathrm{kg}$, while in the sampling point III Xmes -72.5 , and $\mathrm{Sdev}-12.13 \mathrm{mg} / \mathrm{kg}$.

As far as the results of the analyses of the sampling points and the depths of 55-65 cm, we obtained the following values: for the sampling point I, Xmes shows high value $379.8 \mathrm{mg} / \mathrm{kg}$, whereas Sdev $-6.37 \mathrm{mg} / \mathrm{kg}$, for the sampling points II and III the values for Xmes are $85.5 \mathrm{mg} / \mathrm{kg}$ and $96.8 \mathrm{mg} / \mathrm{kg}$, respectively, whereas for Sdev at the sampling points II and III we have obtained 1.80 $\mathrm{mh} / \mathrm{kg}$ and $9.75 \mathrm{mg} / \mathrm{kg}$, respectively.

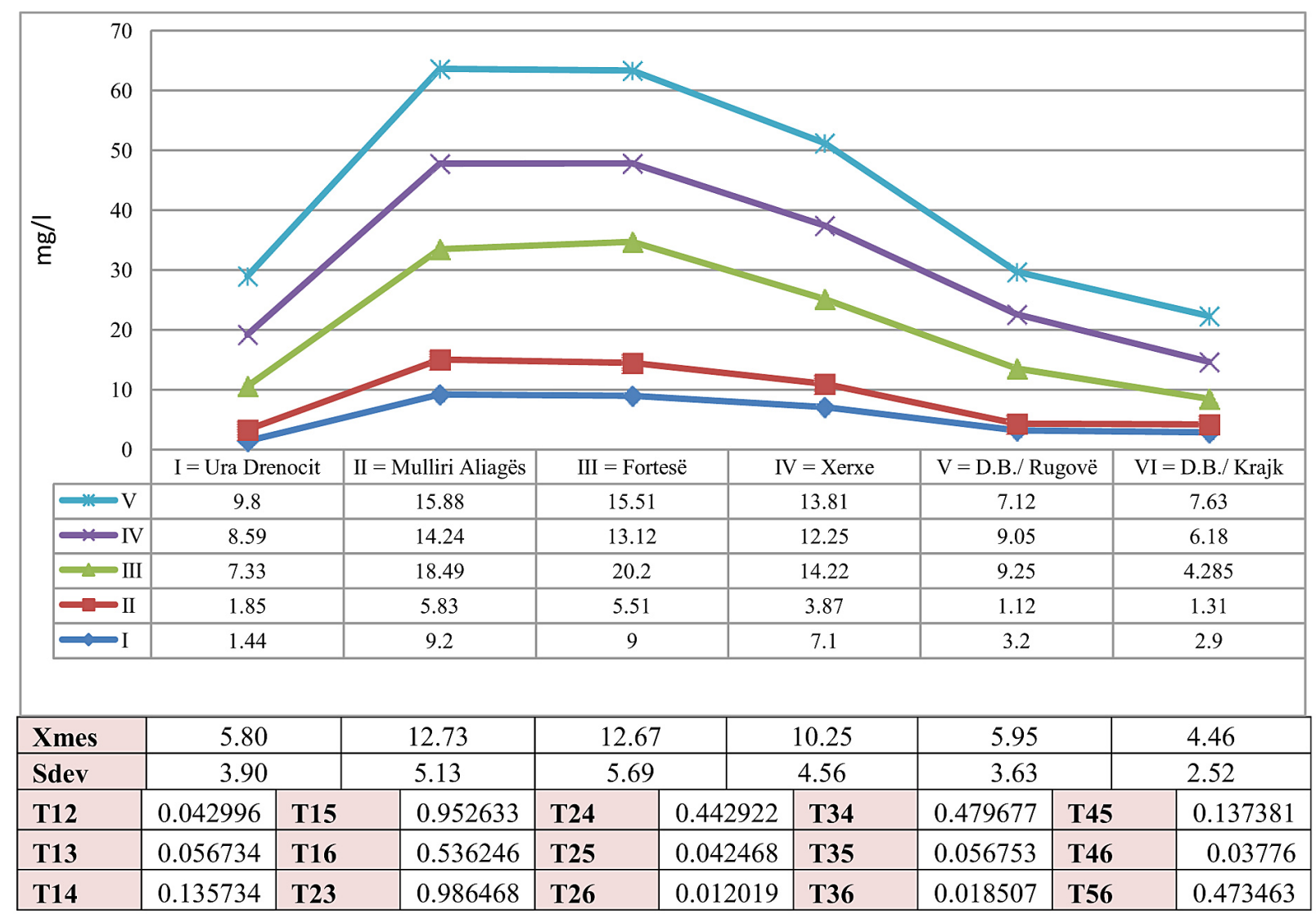

Fig. 2. Results of $\mathrm{BOD}_{5}$ analysis in water samples at sampling sites and periods 


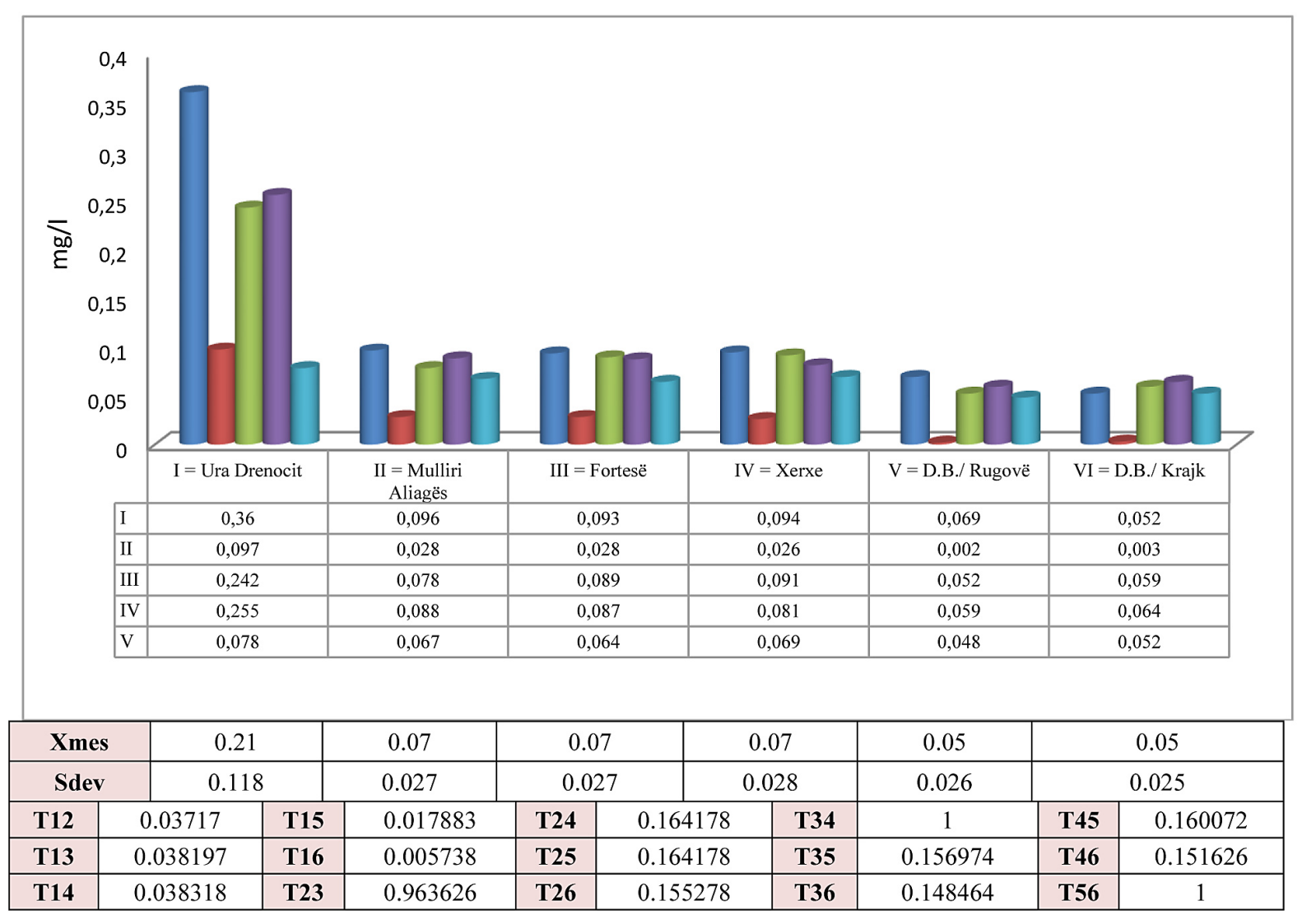

Fig. 3. Results of Ni analysis in water samples at sampling sites and periods.

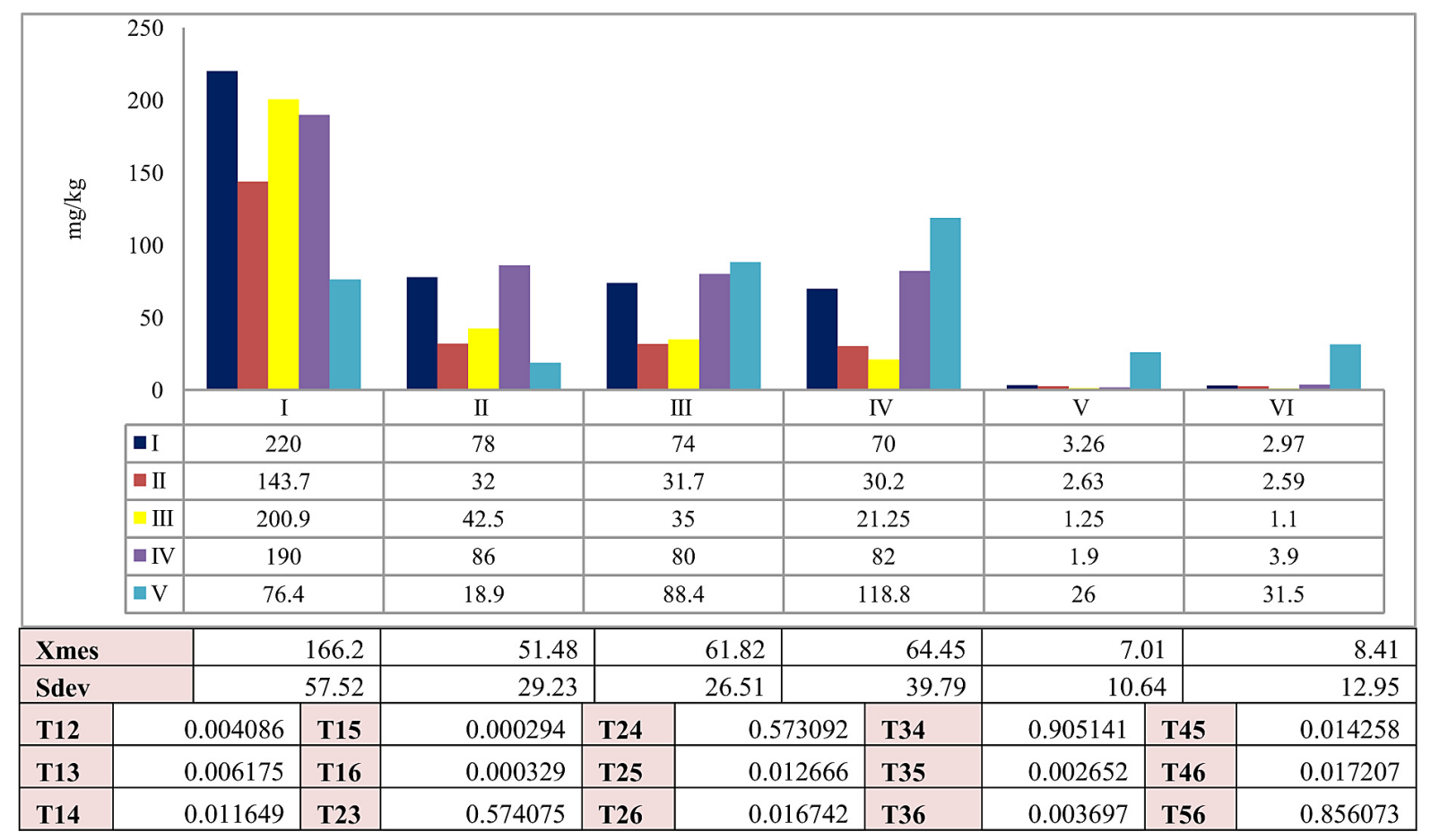

Fig. 4. Results of $\mathrm{Ni}$ analysis in soil samples at site-sampling and periods 


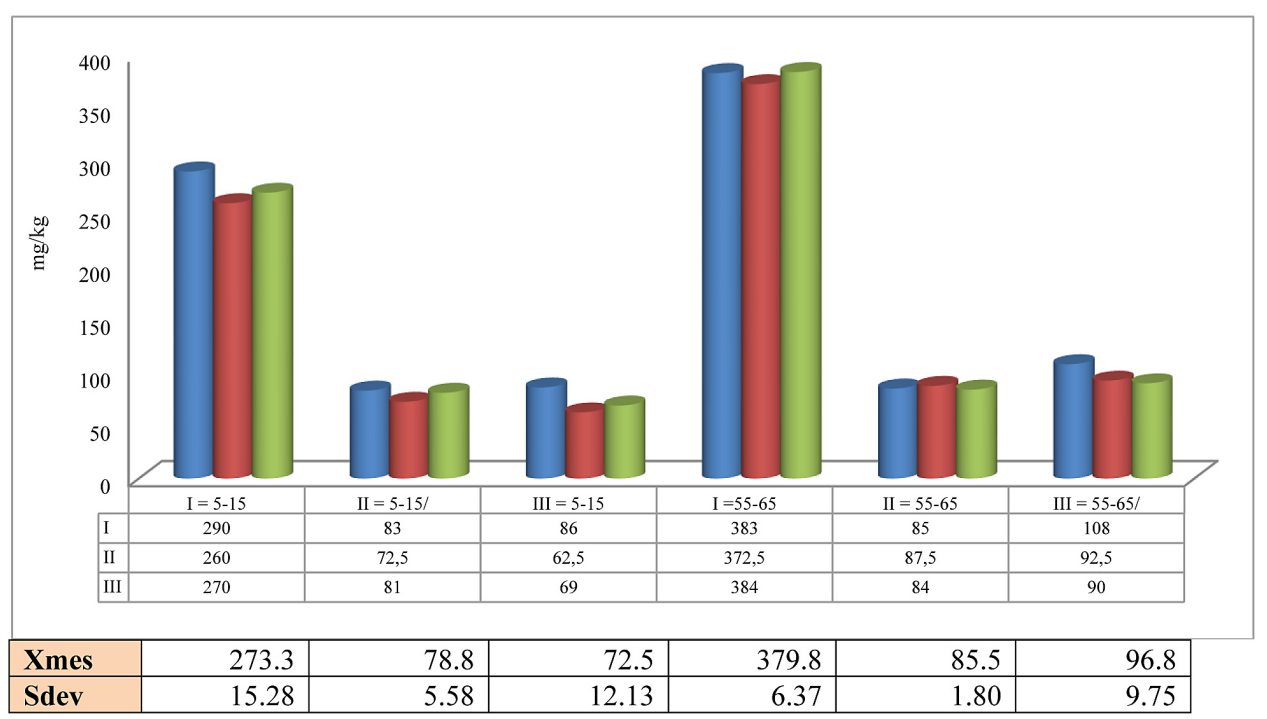

Fig. 5. Results of Ni analysis in sediment samples at site-sampling and periods

\section{CONCLUSIONS}

1. The results of measurements and analyzed parameters indicate that these waters are highly polluted in some localities and mainly belong to $2^{\text {nd }}$ and $3^{\text {rd }}$ category of surface water quality, according to UNECE and the Administrative Instruction on 'Maximum Allowed Concentrations of Substances hazardous to polluted waters, which are discharged into the receiving environment'. According to the experimental results from the sampling samples, it was concluded that sampling site I (ura e Drenocit) at the entrance of Rahovec along the MalishevëRahovec axis belongs to the first class of surface waters excluding TDS, $\mathrm{BOD}_{5}, \mathrm{OD}$ and $\mathrm{Fe}$, which did not show the concentrations close to this class. While analyzing other locations, we concluded that at site II(Winery Plant or Winery), there is very high pollution after the discharge of wastewater and waste of the city, and the waters from the first category that were in the first class can now be classified in the $3^{\text {rd }}$ and $4^{\text {th }}$ category of water quality, excluding TDS and OD, which show even higher concentrations. We also have approximate results at site III(Fortesa), after the discharge of the waters from the Winery. It should be noted that at the time of sampling the factory was with reduced capacity. The site IV (Xerxe) is mostly at third or fourth level (grade) There is also a direct impact on the national road with different pollutants. The location (point of sampling) next to site $\mathrm{V}$ (Rugova) comprises the waters of Drini i Bardhë before the watershed of Rahovec, and from the analysis of laboratory results it turns out that these waters were in the second level water quality level. After the spillage of these waters, according to the results of the site VI (Krajk), there is a slight impact on the pollution of the Drini i Bardhë River. A more realistic state of the current waters of Cerica and Drini i Bardhë can be specified based on the laboratory results from the samples of sediment sampled in the same site and sampling period with those of the waters and those of agricultural lands on the surface and depth of up to $65 \mathrm{~cm}$.

2. At the sampling site I (Ura e Drenocit), to which constituted a reference sampling point, the measurement results in some cases showed a high degree of concentration, especially in the case of heavy metals. High concentrations of heavy metals at this sampling point, compared to others, also showed in sediment samples and agricultural land. It is thought that this concentration of heavy metals comes as a result of the type of soil in this locality, i.e. the composition of the rocks. This area was used as a mineral area from the earliest years. The high values of metals in this water-flow, come from the composition of rocks from the interior of the earth.

3. At the sampling site II, (Mulliri i Aliages), the Cerica River waters mix with the waters discharged from the stream or Rahovec collector, and the results obtained in the laboratory show that there is enormous pollution even against the amount of water that almost doubles the flow. Except heavy metals, other parameters of pollution control, from this point indicate 
the highest degree of concentration. The possibility of pollution is mainly from the domestic waters, without excluding the possibility of contamination by craftsmanship and mini-wine cellars of the Rahovec city.

4. At the sampling site III, (Fortesë), the concentration of the parameters set out in our research did not show a large degree of change with the second place. Although in the course of the river there were possibilities of it cleaning itself, the results showed no difference. The possible cause in this case was pure water from agricultural land along (horn) the Cerica River. Some of these lands watered with the water of this river and, together with fertilizers, insecticides, herbicides, fungicides and other soil ingredients, returned to the River. The potential pollutant is also the wine cellar which discharges untreated waters with high acidity in low quantities. Even the concentrations of samples in sediment and agricultural land did not make any significant changes compared to those in point II (Mulliri i Aliages).

5. At the sampling site IV, (Xerxe), the concentrations of the defined parameters showed a solid decline. The water flow for several kilometres from the sampling point III could clean the river to the expected degree, because this contamination was originated from the flow of water from the village of Sapniq. The potential polluters with high impact on the water pollution of this stream besides domestic waters also include the workplaces adjacent to it. This land is mainly planted with vineyards and other seasonal crops, which are fertilized and sprinkled with various agents. The parameters defined on the working ground (heavy metals) showed lower concentration values, compared to those in the first sampling point.

6. At the sampling site V, (Rugova), the concentrations of water and sediment parameters, determined in the Drini i Bardhë, are diversified compared to those found in the Cerica River. The variability of the concentration was shown in all the sampling periods. These waters were still not affected by the contaminated waters of the Cerica River because the sampling point is selected before unloading.

7. At the sampling site IV (Krajk), the concentrations of the defined parameters were almost to the same as in the sampling point $\mathrm{V}$. The discharge of these waters (the waters of the Cerica River) did not show significant impact because its flow is small compared to the Drini i Bardhë. Likewise, its several-kilometre journey without other polluting discharges allowed its daughter to concentrate pollutants. Low concentrations are mainly indicated for heavy metals dissolved in water.

\section{REFERENCES}

1. Baraj, B., Niencheski L.F., Corradi, C. 1758. Studimi i përmbajtjes se metalit ne guacat e detit Perna (Linneaus) nga brigjet e Atlantikut të Brazilit jugor.

2. Bajraktari, N., Arbneshi, T., Jusufi S., Fejza I., 2008. Water Quality of River Drini i Bardhë, Int. Environmental Application \& Science, Vol. 3 (2): 74-79.

3. Kadastri i Ujërave të ndotura të Kosovës, 1988. KSAK, Prishtinë,

4. Miho A., Çullaj A., Hasko A., Lazo P., Kupe L., Bachofen R., Brandl H., Schanz F., Baraj B., 2005. Gjendja Mjedisore e disa lumenjve të Ultesirës Adriatike Shqiptare, Maj 2002 - Mars 2004, Tiranë.

5. Karl Hofius, UNESCO-s, (2003), Bon.

6. Lee, G.F. and Jones-Lee, A. 1999. Evaluation of Surface Water Quality Impact of Hazardous Chemical Sites. Remediation, 9:87-118.

7. Polić P., Blagojević S., 1999. Teski metali u vodama, Novi Sad, f. 74.

8. Manahan S.E., 1991. Environmental Chemistry, 5 th Edition, Boston.

9. Aubert H., Pinta M., 1997. Trace Elements in soils. elsevier, amsterdam.

10. Smith, W.H. 1974. J. Air. Pollut. control assoc. 26., 753-766.

11. Bajraktari, N., Berisha, G., Berisha, S., 2004. Impact of inert utilization on quality of basin 'Drini i Bardhë', Internacional konference, Prishtina,

12. Alloway, S.C. 1990. Heavy Metals in Soils, Blackie, Glasgow and London.

13. Baraj, B., Niencheski L.F., Trapaga, R.D., Franca, R.G., Cocoli, V., Robinson D., 1999. Study of interference in the flame atomic absorption spectrometric determination of litium by using factorial design. Brazil.

14. Bajraktari, N., Baraj, B., Arbneshi, T., Jusufi, S., 2010. Microelement exploration water flow of Rimnik River, Int. Environmental Application \& Science, vol. 4.

15. Demaku, S. Shehu, I. Ramadani, F. Bajraktari, N. Behrami, A. Bekolli, A., 2016. Impact of the cement factory in 'Elez Han" in pollution of the Water of River Lepec and agricultural soil around of this area, International Journal of Pharmaceutical Sciences Review and Research; Article No. 48, Pages: 266-270.

16. Shehu, I. Bajraktari, N. Demaku, S. Bekolli, A. Malsiu, A., 2016. The Study of Absorption of Heavy Metals from the Soil at Some Vegetables in Anadrinia Region in Kosovo, International Journal of Pharmaceutical Sciences Review and Research, Article No. 59, Pages: 324-329. 